\title{
Artificial factor VIII deficient plasma: preparation using monoclonal antibodies and its use in one stage coagulation assays
}

\author{
VALERIE S HORNSEY, Y G WATERSTON, C V PROWSE From the Edinburgh and South \\ East Scotland Blood Transfusion Service, Royal Infirmary, Edinburgh, Scotland
}

SUMMARY Monoclonal antibodies to factor VIII antigen (VIII:Ag) and von Willebrand factor (vWf:Ag) were immobilised on Sephacryl S-1000 and tested for their ability to deplete normal human citrated plasma of factor VIII. A combination of two antibodies to VIII:Ag and one antibody to vWf:Ag was required to produce plasma containing less than $0.01 \mathrm{IU} / \mathrm{ml}$. Its performance in the one stage coagluation assay of VIII:C was equivalent to that of congenital VIII deficient plasma for the assay of normal and haemophilic plasma and factor VIII concentrates. Storage of freeze dried aliquots of this product at $-20^{\circ} \mathrm{C},+4^{\circ} \mathrm{C}$, and $37^{\circ} \mathrm{C}$ showed that it could be used as a substrate for at least six months when stored at temperatures $+4^{\circ} \mathrm{C}$ and below.

The assay of factor VIII procoagulant activity (VIII:C) is important both in the clinical assessment of patients with haemophilia A and in the production of therapeutic factor VIII concentrates. While VIII:C may be assayed by the two stage clotting,' or chromogenic assay. ${ }^{23}$ most laboratories use the one stage clotting assay ${ }^{4}$ which requires severe haemophilic plasma as a reagent. This has largely been obtained from patients with a congenital deficiency, but the increasing introduction of treatment for use at home has made its supply more uncertain; and concern over viral infectivity of these haemophilic plasmas makes the preparation of artificial haemophilic plasma an attractive proposition.

Artificial haemophilic plasma prepared by mixing partially purified fractions ${ }^{56}$ has not gained widespread acceptance. Normal plasma has been depleted of VIII:C using polyclonal rabbit antibodies, ${ }^{7}$ human antibodies, ${ }^{8}$ and rabbit and human antibodies combined, ${ }^{9}$ while cryosupernatant has been depleted with rabbit antibodies. ${ }^{10}$ Unfortunately, these methods are limited by the availability of suitable human or rabbit inhibitors.

In this study murine monoclonal antibodies to factor VIII antigen (VIII:Ag) and von Willebrand factor (vWf:Ag) were used to deplete normal human plasma of VIII:C and the performance of this reagent in the one stage clotting assay was assessed.

\section{Material and methods}

Sephacryl S-1000 was obtained from Pharmacia (UK)

Accepted for publication 22 December 1987
Ltd. Human plasma was obtained from normal blood donations and was both human immunodeficiency virus (HIV) antibody and hepatitis B antigen negative. Calibrated normal pooled plasma was used as a standard for all assays. Its VIII:C content was $0.9 \mathrm{IU} /$ $\mathrm{ml}$ when assayed against the International Plasma Standard for factor VIII (provided by the National Institute for Biological Standards and Control).

Monoclonal antibodies to VIII:Ag, ESH 1-10, were prepared and purified on protein A-Sepharose 4B by Griffin et al." Purified monoclonal antibodies to vWf:Ag, ESvWf 8, 9, and 10, were prepared in the same manner as ESvWf 1 to $5 .^{12}$

Human IgG to VIII:Ag (80 BU/ml plasma) and rabbit IgG to vWf:Ag were isolated from the corresponding antisera (after recalcification of plasma when necessary) by sodium sulphate precipitation. ${ }^{13}$ The rabbit antiserum was prepared locally. ${ }^{12}$

IgG was immobilised at 1 to $10 \mathrm{mg} / \mathrm{ml}$ settled gel on Sephacryl S-1000 by the low temperature triethylamine-cyanogen bromide method..$^{14}$ The Sephacryl S1000 gel was autoclaved at $121^{\circ} \mathrm{C}$ for 30 minutes, before activation to enhance the subsequent reactivity with $\mathrm{CNBr}$. This improved the activation yield from 5 to $25 \mu \mathrm{mol}$ cyanate $/ \mathrm{ml}$ of gel. The gels were washed and heated for 30 minutes at $56^{\circ} \mathrm{C}$ after coupling of immunoglobulin.

One stage clotting assay of VIII:C, two-site immunoradiometric assay of VIII:Ag, the electro-

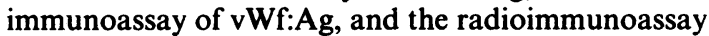
of vWf:Ag have been described previously. ${ }^{12-15}$ The microtray chromogenic assay of VIII:C used was that adapted by Prowse et al. ${ }^{3}$

One stage clotting assays for other factors ${ }^{16}$ and 
fibrinogen ${ }^{17}$ were performed according to established methods.

Endotoxin concentrations were measured by the Limulus assay (Associates of Cape Cod Inc, Massachusetts) and bacterial contamination was measured by adding $1 \mathrm{ml}$ sample to $15 \mathrm{ml}$ tryptone soya agar in a sterile Petri dish at $22^{\circ} \mathrm{C}$ for 48 hours and counting the colonies.

\section{LYOPHILISATION}

Sucrose $(2 \% \mathrm{w} / \mathrm{v})$ was added to the immunodepleted plasma which was freeze dried in $2 \mathrm{ml}$ aliquots and stored under nitrogen at $-20^{\circ} \mathrm{C},+4^{\circ} \mathrm{C}$, and $37^{\circ} \mathrm{C}$. A donation of congenitally factor VIII deficient plasma was treated similarly for comparison.

\section{BATCH ADSORPTIONS USING MONOCLONAL}

ANTIBODIES TO VIII:Ag AND VWF:Ag

To assess whether normal plasma could be depleted of VIII using a single monoclonal antibody, batch immunoadsorption of $1 \mathrm{ml}$ aliquots of normal plasma was performed with $0.1 \mathrm{ml}$ of Sephacryl S-1000 immobilised monoclonal antibody to VIII:Ag (1 mg $\mathrm{IgG} / \mathrm{ml}$ gel) for four hours at room temperature. Ten monoclonal antibodies were tested and the plasma samples were assayed for residual VIII activities. ESvWf 8, 9, and 10 (monoclonal antibodies to vWf:Ag) were immobilised and tested in a similar way.

\section{COLUMN ADSORPTION}

Initial column adsorption experiments involved passing $20 \mathrm{ml}$ of plasma down $1 \mathrm{ml}$ columns of immobilised ESvWf 8 and ESH 8 in separate columns, run in series. ESH 5 was subsequently added to the series and this combination was then tested on a larger scale using 17 $\mathrm{mg}$ of each of the three antibodies as follows. Each monoclonal antibody was coupled to Sephacryl S1000 at $1 \mathrm{mg} / \mathrm{ml}$ settled gel and plasma was passed through three serially connected columns $(1.5 \times 15$ $\mathrm{cm}$ ) containing these gels at a rate of $50 \mathrm{ml} /$ hour - that is 1 column volume per hour. In addition, a precolumn of $10 \mathrm{ml}$ bland Sephacryl S-1000 was included as a clarifying filter. Columns were pre-equilibrated in citrate-saline (15 mM citrate, $150 \mathrm{mM}$ sodium chloride $\mathrm{pH} 7 \cdot 0,3 \mathrm{mM}$ sodium azide) at room temperature, regenerated after passage of plasma with $2 \mathrm{M} \mathrm{KI}, 20$ $\mathrm{mM}$ imidazole (pH 6.5), and then re-equilibrated and stored in citrate-saline at $4^{\circ} \mathrm{C}$.

Fibrinogen concentrations were measured at $10 \mathrm{ml}$ intervals in the initial stages of this work.

\section{TESTS ON DEPLETED AND CONGENITALLY}

\section{DEFICIENT PLASMA}

Normal plasma $(200 \mathrm{ml})$ was processed in one day and the product tested for VIII:C content and for use as a substrate in the one stage assay for VIII:C. Six such

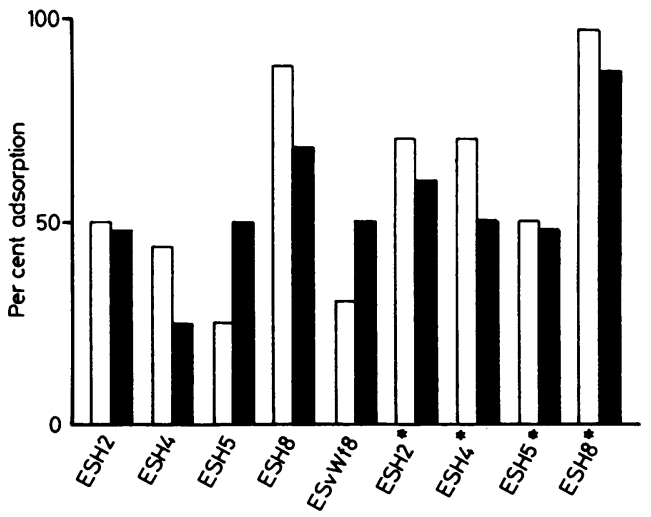

Fig 1 Batch adsorption of plasma with anti-VIII: $\mathrm{Ag}$ and anti-vWf monoclonal antibodies. Per cent adsorption of VIII:Ag $\square$ and VIII:C $\square$ were measured after removal of antibody gel. *Denotes ESH monoclonal antibodies mixed with $E S v W f 8$.

products were mixed together and then freeze dried as described earlier. The phials were then divided into three lots and stored at $-20^{\circ} \mathrm{C},+4^{\circ} \mathrm{C}$, and $+37^{\circ} \mathrm{C}$. Each month aliquots were reconstituted and assayed for various coagulation factors and tested for use as a substrate in the one stage assay for VIII:C up to a period of six months.

A donation of congenitally FVIII deficient plasma was freeze dried and treated in the same way for comparison.

$\mathrm{vWf}: \mathrm{Ag}$ was measured on each of the six products that were to be pooled.

\section{Results}

\section{BATCH ADSOR PTION}

Results were compared with the normal pooled plasma standard (100\%). Assay of the residual FVIII in the plasma showed that a maximum of $88 \%$ VIII:Ag and $68 \%$ VIII:C was adsorbed using ESH 8. Only ESH 5 removed a greater percentage of VIII:C than VIII:Ag from plasma. Mixing together of ESH 2, 4,5 and 8 did not increase these values.

ESvWf 8 and 10 each removed 50\% VIII:C and $30 \%$ VIII:Ag and more than $90 \%$ of the plasma vWf:Ag. ESvWf 9 removed less VIII. Similar experiments using $50 \mu \mathrm{g}$ of ESvWf 8 combined with $50 \mu \mathrm{g}$ of monoclonal antibody to VIII:Ag gave increased adsorption with a maximum $96 \%$ VIII:Ag and $86 \%$ VIII:C being adsorbed when using ESH 8 . The main results are given in fig 1 .

COLUMN ADSORPTION

Use of column rather than batch adsorption yielded much better results and ESvWf 8 alone removed $98 \%$ of VIII:C. ESvWf 8 and ESH 8 together, however, still 
Table 1 Column adsorption of normal plasma

\begin{tabular}{lll}
\hline Monoclonal antibody & $\begin{array}{l}\text { Flow rate } \\
\text { (Column Vol/h) }\end{array}$ & $\%$ VIII:Cremoved \\
\hline ESH 8 & 1 & 92 \\
ESH 8 + ESH 5 & 1 & 96 \\
ESvWf 8 & 1 & 98 \\
ESvWf 8 + ESH 8 & 1 & $98 \cdot 5$ \\
ESvWf 8 + ESH 8 + ESH 5 & 1 & $>99$ \\
& 3 & 95 \\
\hline
\end{tabular}

gave residual VIII:C values that were too high ( $>1 \%)$ to allow the product to be used as a substrate in the one stage coagulation assay for VIII:C. This residual activity was shown to be due to true VIII:C as it could be inhibited by human IgG to VIII:C. To show this, 50 $\mu \mathrm{l}$ of the adsorbed plasma was incubated with $50 \mu \mathrm{l}$ of human anti-VIII:C for two hours at room temperature. At the end of this time, the plasma was assayed for VIII:C activity by the chromogenic assay and this was shown to be less than $1 \%$. Control experiments, in which IgG was replaced by buffer, showed residual VIII activity.

As ESH 5 was the only antibody to VIII:Ag to adsorb a greater percentage of VIII:C than VIII:Ag, it was decided to use this together with ESvWf 8 and ESH 8. Column adsorption was tried with this combination of ESvWf 8, ESH 8, and ESH 5 monoclonal antibody columns and resulted in greater than $99 \%$ adsorption of VIII:C (table 1). When plasma was passed down the columns at a rate of 3 column volumes/hour the adsorption was inadequate.

\section{REGENERATION}

After plasma depletion elution of columns with $2 \mathrm{M}$ $\mathrm{KI}$ and $20 \mathrm{mM}$ imidazole $\mathrm{pH} 6.5$ yielded $50 \%$ of the applied VIII:Ag and vWf:Ag from the gels. Other eluants were tested including $3 \mathrm{M} \mathrm{KSCN}, 5 \mathrm{M}$ urea,

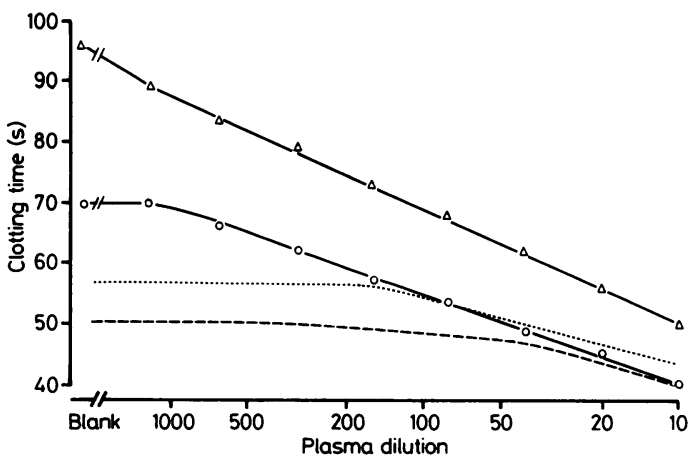

Fig 2 One stage VIII:C assay. Standard curves for immunodepleted plasma $\triangle$, congential deficient plasma $O$, and plasmas containing 2\% -...- and $4 \%$ VIII:C.

and $0.2 \mathrm{M}$ glycine (pH 3.0), but no better results were obtained. The gels were used and regenerated 10 times and still produced a product containing less than $1 \%$ of VIII:C. Between experiments the gels were stored at $4^{\circ} \mathrm{C}$ in citrate-saline buffer containing azide.

\section{TESTS ON DEPLETED AND CONGENITALLY}

DEFICIENT PLASMAS

The six products, which were pooled and freeze dried for the stability study, were each shown to contain less than 1\% VIII:C and VIII:Ag with vWf:Ag, ranging from $<1 \%$ to $3 \%$ of normal pooled plasma. The mean (SD) for other clotting factors was: FII 61 (8); FV 70 (11); FIX 68 (6); FX 93 (22); and FXI 40 (14) (values given as per cent of normal pooled plasma). Fibrinogen concentrations were $2 \cdot 7(1) \mathrm{g} / \mathrm{l}$.

Table 2 gives results for the pooled immunodepleted plasma and for the congenital deficient plasma after freeze drying.

Table 2 Effect of storage on coagulation factor values in lyophilised FVIII:C deficient plasma

\begin{tabular}{|c|c|c|c|c|}
\hline \multirow[b]{2}{*}{ Factor } & \multirow[b]{2}{*}{ After freeze drying } & \multicolumn{3}{|l|}{ After storage } \\
\hline & & 6 months at $-20^{\circ} \mathrm{C}$ & 6 months at $+4^{\circ} \mathrm{C}$ & 2 months at $+37^{\circ} \mathrm{C}$ \\
\hline $\begin{array}{l}\text { Congenitally deficient plasma: } \\
\text { II } \\
\text { V } \\
\text { IX } \\
\text { X } \\
\text { XI } \\
\text { Fibrinogen }\end{array}$ & $\begin{array}{l}130 \\
100 \\
94 \\
105 \\
65 \\
2 \cdot 65\end{array}$ & $\begin{array}{c}102 \\
100 \\
80 \\
96 \\
65 \\
2 \cdot 83\end{array}$ & $\begin{array}{c}102 \\
101 \\
86 \\
96 \\
65 \\
2 \cdot 97\end{array}$ & $\begin{array}{c}101 \\
49 \\
55 \\
70 \\
\text { ND } \\
0 \cdot 82\end{array}$ \\
\hline $\begin{array}{l}\text { Immunodepleted plasma: } \\
\text { II } \\
\text { V } \\
\text { IX } \\
\text { X } \\
\text { XI } \\
\text { Fibrinogen }\end{array}$ & $\begin{array}{c}101 \\
66 \\
74 \\
98 \\
40 \\
2 \cdot 14\end{array}$ & $\begin{array}{l}82 \\
60 \\
72 \\
85 \\
40 \\
2 \cdot 08\end{array}$ & $\begin{array}{l}83 \\
52 \\
73 \\
86 \\
40 \\
2.06\end{array}$ & $\begin{array}{l}72 \\
25 \\
43 \\
65 \\
\text { ND } \\
0 \cdot 79\end{array}$ \\
\hline
\end{tabular}

Results compared with normal pooled plasma $=100 \%$, except fibrinogen $(\mathrm{g} / \mathrm{l})$ 


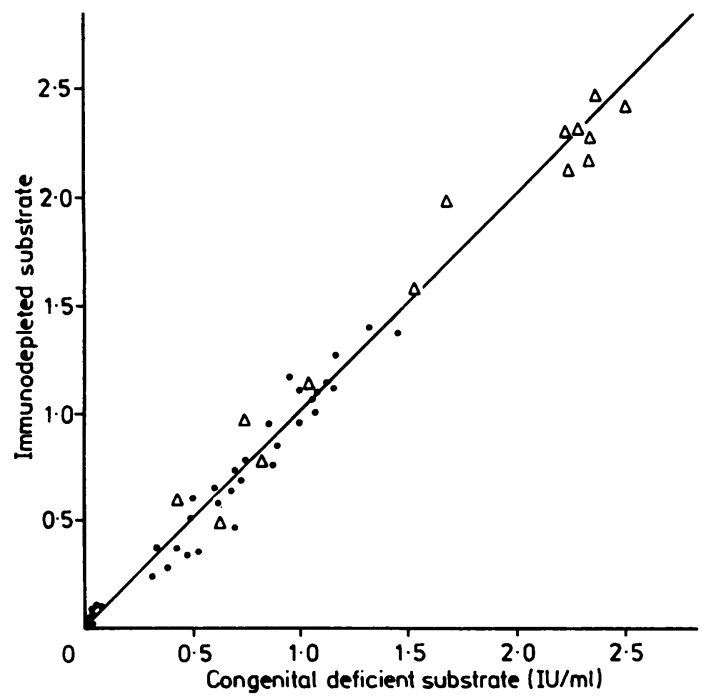

Fig 3 Assays on haemophilic plasmas, normal plasmas, and VIII concentrates using immunodepleted plasma compared with identical samples assayed using congenital substrate. $(\Delta=$ concentrates plotted on $1 / 5$ scale) $n=51, r=0.99$ $p<<0.001$ with a regression equation of immunodepleted $=1.00$ congenital $-0.005(\mathrm{IU} / \mathrm{ml})$.

Fig 2 shows standard curves obtained in the one stage assay when using congenitally deficient plasma, deficient plasma produced as described above containing less than $1 \%$ VIII:C, plasma adsorbed with ESvWf 8 (containing $2 \%$ VIII:C), and plasma adsorbed by using ESH 8 together with ESH 5 (containing $4 \%$ VIII:C).

When newly prepared columns were used for the first time $\simeq 50 \%$ of fibrinogen was removed from the first $10-20 \mathrm{ml}$ of plasma. The first $30 \mathrm{ml}$ of plasma from such runs was therefore rejected. After regeneration of the column subsequent runs yielded plasma with fibrinogen concentrations that were always within the normal range.

\section{STABILITY OF FREEZE DRIED PRODUCT AND}

CONGENITALLY DEFICIENT PLASMA

The freeze dried samples were stored at $-20^{\circ} \mathrm{C}$, $+4^{\circ} \mathrm{C}$, and $+37^{\circ} \mathrm{C}$ and aliquots were reconstituted

Table 3 Assays on plasma from patients with von Willebrand's disease

\begin{tabular}{llll}
\hline Case No & $\% v W f:$ Ag & $\begin{array}{l}\% \text { VIII:C } \\
\text { (congenital) }\end{array}$ & $\begin{array}{l}\% \text { VIII:C } \\
\text { (immunodepleted) }\end{array}$ \\
\hline 1 & 16 & 20 & 20 \\
2 & 28 & 36 & 36 \\
3 & 19 & 34 & 30 \\
4 & 13 & 16 & 14 \\
\hline
\end{tabular}

and tested at monthly intervals for six months. After six months of storage at $-20^{\circ} \mathrm{C}$ and $+4^{\circ} \mathrm{C}$, the immunodepleted plasma had a concentration of $40 \%$ of factor XI compared with a value of $65 \%$ for the freeze dried congenitally deficient plasma.

Table 2 shows the residual concentrations of coagulation factors at six months (two months for plasma stored at $+37^{\circ} \mathrm{C}$ ).

\section{COMPARISON WITH CONGENITALLY DEFICIENT PLASMA FOR ONE STAGE ASSAYS}

Fifty one samples, including 29 normal plasmas, eight haemophilia A plasmas (before and after infusion of VIII concentrates), and 14 VIII concentrates, were assayed for VIII:C using both the immunodepleted plasma and congenitally deficient plasma. These showed excellent correlation $r=0.99$ (fig 3). Regression analysis of these data showed that the potencies could be fitted to the equation: immunodepleted $=1.00$ congenital $-0.005(\mathrm{IU} / \mathrm{ml})$.

No drift was found in clotting times during the assay period (up to 60 minutes) when using the immunodepleted plasma.

\section{BACTERIAL TESTING}

Bacteria have deleterious effects on plasma products. Checks were therefore carried out on normal and depleted plasma to check if column passage resulted in contamination. The column had been used and regenerated five times before this test. Passage down the antibody column resulted in a minor increase in endotoxin concentrations from undetectable to $2 \mathrm{ng} /$ $\mathrm{ml}$ and in bacterial contamination from 5 to 30 colony forming units $/ \mathrm{ml}$.

\section{ASSAYS ON PLASMA FROM PATIENTS WITH VON WILLEBRAND'S DISEASE}

Four patients with von Willebrand's disease had their VIII:C concentrations assayed by the one stage method using both congenitally deficient and immunodepleted plasma (table 3 ).

\section{Discussion}

Monoclonal antibodies to vWf:Ag and VIII:Ag provided a means of producing an FVIII deficient substrate from fresh plasma which was both HIV antibody and hepatitis $B$ antigen negative and which was also readily available in quantity.

Takase et al recently reported a similar method for the preparation of VIII-immunodepleted plasma using a monoclonal antibody to vWf:Ag and two to VIII:Ag. ${ }^{18}$ Their process, however, depletes cryosupernatant plasma. While the procedure described in this study was also capable of removing all detectable VIII from cryosupernatant, the product obtained had 
reduced concentrations of fibrinogen which could possibly result in long clotting times when used as a substrate in the one stage VIII assay. The antibodies used in this study are also available commercially (Bioscot Ltd) and the method is thus potentially applicable in any reasonably equipped laboratory.

The two anti-VIII:Ag monoclonal antibodies used by Takase $e t$ al are directed to opposite ends of the VIII:Ag molecule. ${ }^{18}$ Epitope maps were not available for the antibodies used in this study and the antibodies were chosen on the basis of the results summarised in fig 1 , although recent preliminary results suggest that they also are directed to the heavy (ESH 5) and light (ESH 8) chains of factor VIII. The anti-vWf:Ag antibody will adsorb the forms of VIII:Ag which are complexed with vWf:Ag. As ESH 8 adsorbed the greatest amount of VIII:Ag it was the natural choice for this work and ESH 5 was chosen as being the only antibody to adsorb a greater proportion of VIII:C than VIII:Ag. This antibody possibly recognises a form of VIII:Ag which is also biologically highly active. These three antibodies together were successful in removing more than $99 \%$ of VIII:C from plasma.

As the results show the same antibodies give greater adsorption in column experiments than in the batch ones. A column of ESvWf 8 alone was capable of removing $98 \%$ VIII:C from plasma. As ESvWf 8 has been shown by methods described in Hornsey et al to bind only to vWf and not to VIII:Ag, ${ }^{12}$ then either this $98 \%$ VIII:C must have been complexed with the vWf or, more likely, some of the adsorption observed in this small scale trial was due to non-specific binding to the column matrix.

The performance of the columns did not seem to be reduced after 10 runs, even though regeneration experiments only indicated $50 \%$ recovery of the VIII:Ag and vWf:Ag from the columns. This could indicate a possible underutilisation of the gel capacity and it may be possible to increase the load of plasma processed before regeneration becomes necessary. A proportion of the two antigens, however, may be destroyed or changed during regeneration, resulting in an underestimate of antigen yield.

The substrate produced is also very low in vWf:Ag, with values of between $1 \%$ and $3 \%$ of normal plasma. It has been suggested that these low values of vWf:Ag will affect the results obtained when assaying VIII:C in plasma from patients with von Willebrand's disease who have low concentrations of both $\mathrm{vWf}: \mathrm{Ag}$ and VIII:C. Muntean et al found an increase in VIII:C values when assaying plasma low in vWf by using a substrate which has been depleted of both VIII:C and vWf. ${ }^{19}$ Mertens et $a l^{20}$ and McPherson et al ${ }^{11}$ have shown that vWf does not affect the VIII:C promoted activation of factor $\mathrm{X}$ by IXa in a purified system. The small number of results obtained here (table 3 ) indicate that this substrate may be used in assaying plasma concentrations of VIII:C in patients with von Willebrand's disease.

The freeze dried product was tested in seven laboratories in the United Kingdom. Three laboratories reported that it was perfectly acceptable for all their purposes; two said it could be used for assay down to FVIII values of $0.01 \mathrm{IU} / \mathrm{ml}$; the remaining two found the clotting times too long to be acceptable, possibly because they used manual one stage assay techniques with fairly short activation times. These long clotting times could result from the somewhat reduced concentrations of factor XI, and possibly the other contact factors in the product and, therefore, care should be taken during production to avoid such losses by, for example, siliconising all columns. Even with the long clotting times, standard curves were reported which were of comparable slope to those obtained using congenitally deficient plasma or other immunodepleted commercially available substrates.

This substrate can be stored for at least six months at temperatures $+4^{\circ} \mathrm{C}$ and below. At $+37^{\circ} \mathrm{C}$ a fairly rapid loss of performance as a substrate was seen (table 2), possibly due to inactivation of factor $\mathrm{V}$ and fibrinogen. This was seen in both the immunodepleted product and the congenitally deficient plasma.

The factor VIII depleted plasma described should be of great value to laboratories performing routine automated one stage coagulation assays for VIII:C in normal plasma, VIII concentrates, and haemophilic plasmas.

We thank Alistair McGregor for help in the initial part of the work and acknowledge Bioscot Ltd for $\mathrm{Mr}$ McGregor's financial support. Thanks also go to Dr Micklem for the monoclonal antibody production; Adam McGill, John Baillie, and Iain Greig for coagulation factors assays; Dr Griffin for elution studies using immobilised anti-VIII:Ag; Petra Eaglesfield, Stephen Lees, Karen McLaughlin, Dr Takase, Dr Austen and Ian Abbott for testing the product in their laboratories; David Black for freeze drying; the staff at the Protein Fractionation Centre for the bacteriological testing; Margaret Currie for typing this manuscript and Drs Pepper and Fatori for help and support. This work was supported in part by a grant K/MRS/50/C500 from the Scottish Home and Health Department to Drs K James and D B L McClelland.

\section{References}

1 Biggs R, Eveling J, Richards G. The assay of anti-haemophilic globulin activity. Br J Haematol 1955;1:20-34. 
2 Rosen S. Assay of factor VIII with a chromogenic substrate. Scand J Haematol 1984;33:(S 40) 139-45.

3 Prowse CV, Hornsey V, McKay G, Waterston Y. Room temperature microtray chromogenic assay of factor VIII:C. Vox Sang 1986;50:21-5.

4 Hardisty RM, MacPherson JC. A one-stage factor VIII (antihaemophilic globulin) assay and its use on venous and capillary plasma. Thromb Diath Haem 1962;7:215-29.

5 Nyman D. The preparation of an artificial reagent for the onestage factor VIII assay. Thrombos Diath Haem 1970;23:306-12.

6 Chantarangkul V, Ingram GIC, Thorn MB, Darby SC. An artifical "Haemophilic" plasma for one-stage factor VIII assay. Br J Haematol 1978;40:471-88.

7 Tran T H, Duckert F. Preparation of factor VIII-free plasma by immunoaffinity chromatography on insolubilised antibodies against factor VIII-related antigen. Haemostasis 1983;13:73-7.

8 Exner T, Rickard KA, Speers S. Factor VIII deficient plasma for laboratory tests prepared from normal plasma and a human antibody. Haemostasis 1977;6:157-62.

9 Furlan M, Felix R, Beck EA. Preparation of factor VIII-deficient plasma by immunoadsorption. Vox Sang 1979;36:342-6.

10 Ofosu F, Cassidy K, Blajchman MA, Hirsh J. Immunodepletion of human plasma factor VIII. Blood 1980;56:604-7.

11 Griffin BD, Micklem LR, McCann MC, James K, Pepper DS. The production and characterisation of a panel of ten murine monoclonal antibodies to human procoagulant factor VIII. Thromb Haemostas 1986;55:40-6.

12 Hornsey V, Micklem LR, McCann MC, et al. Enhancement of factor VIII von Willebrand factor ristocetin cofactor activity by monoclonal antibodies. Thromb Haemostas 1985;54:510-14.

13 Wright JF, Hunter WM. A convenient replacement for cyanogen bromide-activated solid phases in immunoradiometric assays. $J$
Immunol Methods 1982;48:311-25.

14 Kohn J, Wilchek M. A new approach (cyano-transfer) for cyanogen bromide activation of Sepharose at neutral $\mathrm{pH}$ which yields activated resins free of interfering nitrogen derivatives. Biochem Biophys Res Comm 1982;107:878-84.

15 Hornsey VS, Griffin BD, Pepper DS, Micklem LR, Prowse CV. Immunoaffinity purification of factor VIII complex. Thromb Haemostas 1987;57:102-5.

16 Austen DEG, Rhymes IL. A laboratory manual of blood coagulation. Oxford: Blackwell Scientific Publications, 1975.

17 Ellis BC, Stransky A. A quick and accurate method for the determination of fibrinogen in plasma. J Lab Clin Med 1961;58:477-88.

18 Takase T, Rotblat F, Goodall AH, et al. Production of factor VIII deficient plasma by immunodepletion using three monoclonal antibodies. Br J Haematol 1987;66:497-502.

19 Muntean W, Hathaway WE, Montgomery RR. Influence of high molecular weight factor VIII on the measurement of low molecular weight factor VIII procoagulant in different assay systems. Br J Haematol 1982;51:649-58.

20 Mertens K, van Wijngaarden A, Bertina RM. The role of factor VIII in the activation of human blood coagulation factor $\mathrm{X}$ by activated factor IX. Thromb Haemostas 1985;54:654-60.

21 McPherson J, Soberano ME, Macdonald C, Zucker MB. Evidence that von Willebrand factor is not required for the clotting of plasma in the presence of platelets and kaolin (Hardisty-Hutton Test). Thromb Haemostas 1984;51:272-4.

Requests for reprints to: Mrs V S Hornsey, Blood Transfusion Service, Royal Infirmary, Edinburgh EH3 9HB, Scotland. 